\title{
Architecture_MPS
}

\section{Emancipating the Image: The Beijing Olympics, Regeneration, and the Power of Performance}

Carol Mei Barker ${ }^{1, *}$

How to cite: Barker, C. M. 'Emancipating the Image: The Beijing Olympics, Regeneration, and the Power of Performance.' Architecture_MPS, 2013, 2(1): 1, pp. 1-18. DOI: https://doi.org/10.14324/111.444.amps.2013v2i1.001.

Published: 01 January 2013

\section{Peer Review:}

This article has been peer reviewed through the journal's standard Editorial double blind peer review.

\section{Copyright:}

(C) 2013, The Author(s). This is an Open Access article distributed under the terms of the Creative Commons Attribution License (CC-BY) 2.0 https://creativecommons.org/licenses/by/2.0/, which permits re-use, distribution and reproduction in any medium, provided the original author and source are credited • DOI: https://doi.org/10.14324/111.444.amps.2013v2i1.001

\section{Open Access:}

Architecture_MPS is a peer-reviewed open access journal. 


\title{
Title: Emancipating the Image: The Beijing Olympics, Regeneration, and the Power of Performance
}

\author{
Author: Carol Mei Barker
}

\section{Architecture_media_politics_society. vol. 2, no.1.}

January 2013

Affiliation: Media School, The University of Bradford, UK

\begin{abstract}
:
“In China, what makes an image true is that it is good for people to see it.” - Susan Sontag, On Photography, 1971

In The Practice of Everyday Life, Michel de Certeau gazes down upon New York City from the $110^{\text {th }}$ floor of the World Trade Centre and sees the island of Manhattan as an image. In particular, he witnesses the famous Manhattan skyline as a powerful 'image-text' containing a multiplicity of meanings, interpretations, and symbols. Considering the possibilities of the city as visual simulacrum he asks: "[i]s the immense texturology spread out before one's eyes anything more than a representation; an optical artefact?” Twenty or so years after De Certeau wandered the streets of New York and pondered its pictorial power, such a perspective can be applied to Olympic and Post Olympic Beijing.
\end{abstract}

The Olympic Games gave the world an opportunity to read Beijing’s powerful image-text following thirty years of rapid transformation. David Harvey argues that this transformation has turned Beijing from “a closed backwater, to an open centre of capitalist dynamism.” However, in the creation of this image-text, another subtler and altogether very different image-text has been deliberately erased from the public gaze. This more concealed image-text offers a significant counter narrative on the city's public image and criticises the simulacrum constructed for the 2008 Olympics, both implicitly and explicitly. It is the 'everyday' image-text of a disappearing city still in the process of being bulldozed to make way for the neoliberal world's next megalopolis. It exists most prominently as a filmic image text; in film documentaries about a 'real' hidden Beijing just below the surface of the government sponsored 'optical artefact.' Film has thus become a key medium through which to understand and preserve a physical city on the verge of erasure. 


\title{
Title: Emancipating the Image: The Beijing Olympics, Regeneration, and the Power of Performance
}

\author{
Author: Carol Mei Barker
}

Architecture_media_politics_society. vol.2, no.1.

January 2013

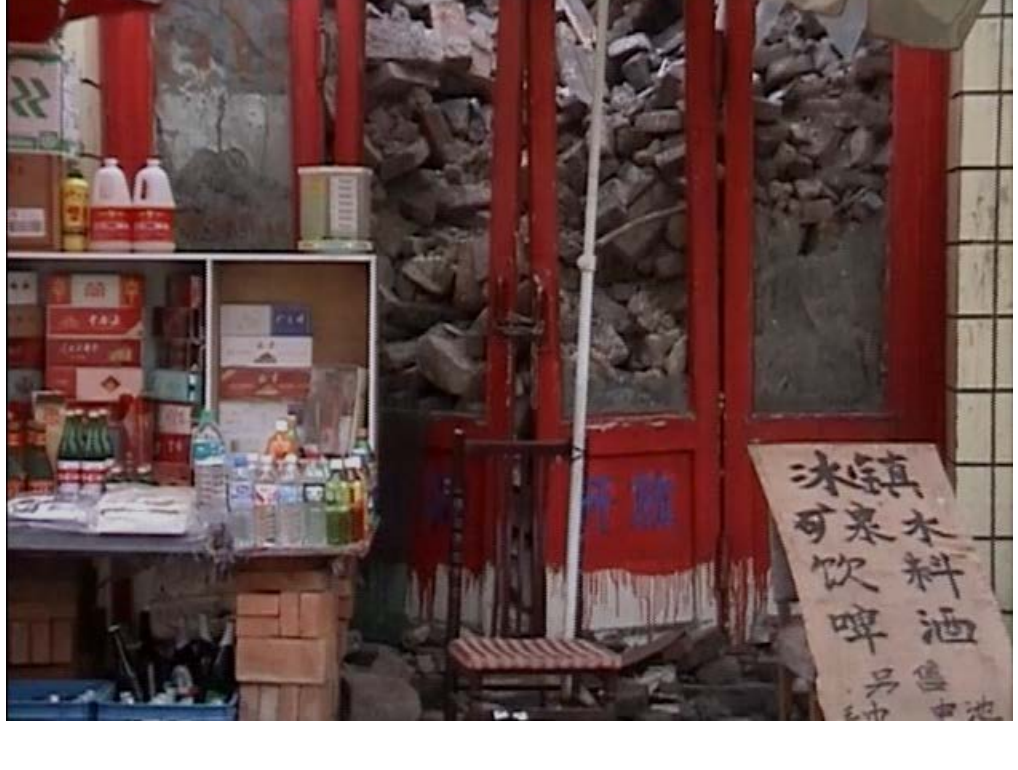

Meishi Street (2006) courtesy of Icarus Films

'In China, what makes an image true is that it is good for people to see it'.

Susan Sontag, On Photography, 1971

In The Practice of Everyday Life, Michel de Certeau gazes down upon New York City from the $110^{\text {th }}$ floor of the World Trade Centre and sees the island of Manhattan as an image. In particular, he witnesses the famous Manhattan skyline as a powerful 'image-text' containing a multiplicity of meanings, interpretations, and symbols. Considering the possibilities of the city as visual simulacrum he asks: "[i]s the immense texturology spread out before one’s eyes anything more than a representation; an optical 


\section{Amps}

artefact?" ${ }^{1}$ Twenty or so years after De Certeau wandered the streets of New York and pondered its pictorial power, such a perspective can be applied to Olympic and Post Olympic Beijing.

The Olympic Games gave the world an opportunity to read Beijing's powerful image-text following thirty years of rapid physical and socio-economic transformation. David Harvey argues that this transformation has turned Beijing from "a closed backwater, to an open centre of capitalist dynamism.”" However, in the creation of this image-text, another subtler, older and altogether very different image-text has been deliberately erased from the public gaze. This more concealed image-text offers a significant counter narrative on the city's public image and criticises the virtual simulacrum constructed for the 2008 Olympics, both implicitly and explicitly. It is the 'everyday’ image-text of a disappearing city that is still in the process of being bulldozed to make way for the neoliberal world's next megalopolis. It exists most prominently as a filmic image text; in film documentaries about a 'real' hidden Beijing just below the surface of the government sponsored 'optical artefact.' Film has thus become a key medium through which to understand and preserve a physical city on the verge of erasure.

Every four years, the Olympics not only showcases sport but exhibits the political, economic and aesthetic prowess of its host city. In many cases, as in that of Beijing, it is used to re-brand the host as a 'global city.' In the Beijing case, this formed part of a broader attempt to demonstrate China's growing international status which has seen it undergo enormous, and at times complex and controversial, 'image maintenance.' In the years between winning the bid and the grand execution of the Olympic project, the city saw the construction of what Xuefei Ren calls, 'new State spaces'; spaces developed entirely for the accommodation of 'transnational architectural production'; the construction of buildings whose function was to increase the circulation of both symbolic and investment capital. ${ }^{3}$ These new, globally connected spaces and their 'statescrafts, ${ }^{4}$ were part of an interrelated urban renewal programme that helped to redefine Beijing's image, integrate it into the global business community, and improve the reputation of the nation at large.

Since the early days of the reform period, the creation of a visual image for Beijing as a global city has been an official objective. In order to adopt this “global city look,” international architects have been getting invited by the government to collaborate on joint venture projects for years; the aim being to target foreign investment and tourism. ${ }^{5}$ In a sense, the Olympics were just the latest phase of an ongoing process that arguably injected much needed public resources into the long term project, and garnered public support for it at a crucial moment. It helped transform and reconfigure the city generally, and turned specific impoverished residential areas into gentrified hotspots - through huge infrastructural 


\section{Amps}

investments and the development of numerous tourist and consumer spaces.

However, issues of consent are key to 'image maintenance' during such phases of high profile development, as the acquisition of symbolic capital through the neoliberalisation of urban space has real tangible impacts on people's lives. In her 2007 essay on the 'conspicuous construction' of an Olympic metropolis, Anne Marie Broudehoux claims that the Chinese government's diversion of large sums of public money, resources and time, into building the spectacle of Olympic Beijing, actually contributed to the 'profound inequalities that have come to epitomise China's transition to capitalism within an autocratic political system. ${ }^{6}$ She goes on to suggest that the brutality of China's economic rise was highlighted with unusual clarity by the race to transform Beijing into an Olympic spectacle; as this spectacle depended largely on the exploitation of cheap labour, and the State's ability to confiscate land from residents in the name of "public interest., "7

She suggests that in securing mass compliance for its hegemonic architectural and urban reformulations, the Olympics was bound up with a State legislative agenda. That agenda was mobilised by political actors such as the media, and was intended to provide an intoxicating 'value based discourse' that would 'boost morale,' but which would also 'instil fear' into potential dissenters. ${ }^{8}$ With regard to morale, particular cultural and traditional values, such as nationalism and civic pride, were 'rejuvenated with Olympic spirit' to work as both a distraction, and justification, for large-scale transformations that were resulting in significant local upheaval. To contain dissent, and therefore 'maintain image,' heightened security measures such as an increased use of CCTV and an increased military presence on the streets, were brought to the fore. It was a highly visible approach to civil discipline that justified itself by placing emphasis on public safety and protection, but which reconfigured the question of security around discourses of fear. It was through a combination of these techniques, calling upon national sentiment and inducing fear amongst dissenters, that the huge social and spatial changes required could be carried out with little public scrutiny and general consent.

Despite such spectacular efforts to mask reality and sedate the masses, resistance to changes was inevitable. However, in an authoritarian state where public protest and dissent are heavily suppressed, struggles over such brutal changes often took place in the realm of the symbolic. ${ }^{9}$ As protest against global performance and representation was often carried out at a local level, it also became a struggle between the global and the local. Broudehoux highlights the attempts of many exploited Beijing citizens to draw media attention to their injustices; something particularly prevalent amongst overworked and unpaid construction workers and residents of demolished localities, who were forcibly evicted from their 


\section{Amps}

homes. $^{10}$

In some cases, the only way that powerless citizens could publicly protest was by jumping off high-rise buildings which, at the time, became a relatively common form of suicide. It was dubbed locally tiao lou xia (jumping off buildings to show). ${ }^{11}$ The concept of 'showing' is key here, as is reclaiming the spectacle. The aim was to reclaim the 'power of showing,' or simply the 'power of being seen.' The mainstream media has the power to show, but also to not show. Censoring the presentation of these protests was not only key to lessening the chance for wider resistance to local developments, it was also analogous to the government's ‘censoring' of Beijing’s public face; the eviction and demolition of old, low-income communities literally censoring all visible signs of poverty and backwardness from the city centre.

\section{China's Image Problem and Olympic Solution: The City Brand}

The Olympics, like all mega events held in large globalising cities, is about 'being looked at.' According to some commentators such as Del Olmo, Broudehoux and Poynter, hosting this kind of mega-event is nothing more than a conspicuous form of global competitiveness and a highly visible strategy for financing and accelerating urban development. ${ }^{12}$ Michel de Certeau’s perspective on Manhattan’s 'image text' in the early 1980s, underscored this idea through the phenomenon of city rebranding. In this context the image maintenance of New York is an attempt to fit in with, and promote, the city and its free market agenda.

Following this, David Harvey regards 1970s New York City as the first global city to strategically reconfigure its spatial and economic landscape, to create a 'good business climate' that would bolster and sustain America's international status. ${ }^{13}$ As with historic New York, Beijing's economic rise in the past thirty years has required a redefinition of its image. That image has had to reflect the city's, and the nation's, new grand narrative of free market economics and global power. However, unlike New York, since the beginning of China's economic reforms the country has developed a 'particular kind of market economy that increasingly combines a neoliberal economy with authoritarian centralised control. ${ }^{14}$ This is a complicated image and a double sided game highlighted by people like Joshua Cooper-Ramo, who argues that both positive and negative views of China are linked to it.

Positive views tend to be associated with the country's rapid economic growth and opportunities relating to the free market. However, contradictory concerns about poverty, human rights, corruption and 


\section{Amps}

exploitation are connected to the same market reform processes and its backdrop of political authoritarianism. In order for China to control its image, and thus ensure that it remains positive, the country needs an image that is powerful enough to deflect its underlying reality. This issue is of such fundamental importance to the future that Cooper-Ramo suggests that it will actually 'determine the future of Chinese development and reform. ${ }^{, 15}$ For Cooper-Ramo, the way in which the country will develop in the future will be intrinsically linked to internal and external consensus it can forge, and the way it is perceived internally and externally will be central to that.

As a conspicuous channel through which to gain global prestige and attention, the Beijing Olympics was seized upon as an opportunity to rebrand the country and the city. Through the Olympics, resources were invested into reconfiguring the host city materially, in a way that would boost symbolic capital, concepts of modernity, and ensure an image of global capitalist integration. Externally, this all contributes to the creation of a positive image that will facilitate the country's continued integration into the network of international capital investment. Internally, these developments were also used to forge an image of the country as one that was moving forward together, and through consensus. The 'positive image' of the Olympics themselves was important in this regard in that the positive values of the 'Olympic ideals' could also be interwoven into internal discourses about the benefits of modernisation. This was important to garner support for the specific developments associated with the Olympics, but was also important in creating a more positive climate for the social and economic changes required by China's neoliberalising agenda more generally; an agenda resulting in ever greater social and economic inequalities from which the Olympics could be seen as merely a distraction and a smokescreen.

\section{Olympic Beijing: Harmonious Society or Fantasy City?}

In 2005 Prime Minister Hu Jintao sought to boost China’s image by implementing a domestic social policy called 'Harmonious Society'; a social policy guideline aimed at establishing the image of societal balance and unity in China. It has been widely speculated that this nationalist discourse was developed in response to the widening wealth gap; its function being to ease the possibility of social and political unrest and to justify the suppression of dissent. As a form of political theatre, Harmonious Society was central to China's Olympic quest ${ }^{16}$ as it resonated with the 2004 Olympic Charter and Code of Ethics, that now seeks to emphasise 'the preservation of human rights, unity and harmony'. This association played a part in China's Olympic bid, but it also gave the Harmonious Society policy greater credibility inside China by appropriating the more 'independent' Olympic ideals. This in turn allowed the government to 


\section{Amps}

justify some of the more unpalatable consequences of Olympic urban developments and, furthermore, allowed the 'new State spaces' such as the Olympic Stadium (Birds Nest), the Watercube, the National Theatre (the Egg), and the CCTV Tower, to be presented as internally beneficial and not wholly designed according to the needs of external visitors and the international media.

The new 'State spaces' generated symbolic capital that was circulated globally through the currency of images that recreated the 'official' version of the city for the world's media. Each state sponsored megaconstruction, although unique in style, shared internationally branded design credentials, hyper modern 'sci-fi' aesthetics, and the image defining 'soft power' objectives of 'image creation.' The Egg was completed in 2007 despite protests about its price tag, which was estimated at ten times the government's annual spending on poverty alleviation. ${ }^{17}$ The director of this grandiose architectural project described it as 'a concrete example of China's rising soft power and comprehensive national strength, ${ }^{18}$ and thus suggested that its powerful image-text implications outweighed the problem of its cost. Along with Beijing Airport's Terminal 3, 'these "statescrafts" indicated the emergence of a new kind of state space; space produced by global flows of architectural design which accommodate state functions and articulate national ambitions. ${ }^{19}$

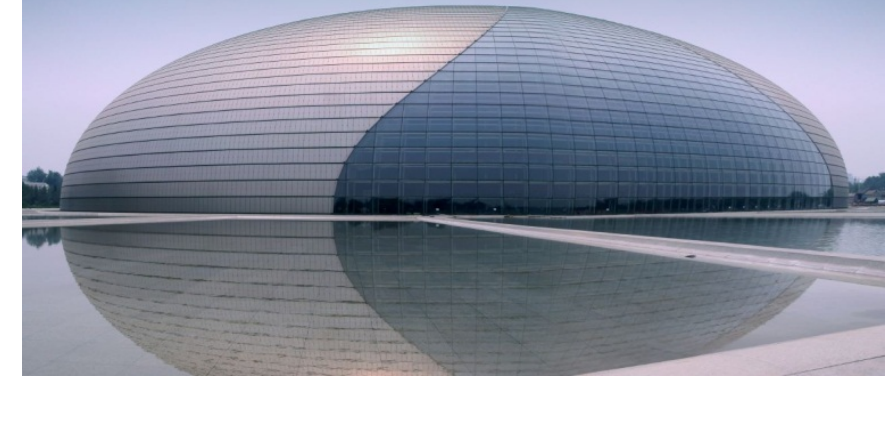

'The Egg' (Beijing National Theatre). Opened 2007. Architect: Paul Andreu

Speaking a language of power and wealth, these projects reduced Beijing to what Hannigan refers to as an archetypal 'Fantasy City'; ${ }^{20}$ a city made up of fragments of an urban landscape that are 'theme-centric,' aggressively branded and selectively preserve the local and historic in ways generally tied to their profitmaking potential. The result was the kind of spectacle that can attract and accommodate tourism, international investment and consumption, and an increase in service industries. However, it was also a spectacle completely at odds with the Harmonious Society discourse; the design of architectural 


\section{Amps}

spectacles that meet the needs and desires of visitors, rather than the accommodation of the practical needs of the Chinese people, being the exact opposite of a discourse aimed at promoting societal unity and harmony. ${ }^{21}$

In this sense, Beijing 2008 was typical of all Olympics up until the 2012 Games in London, and falls into line with Gavin Poynter's 2006 study on the urban Olympic legacy. This suggests that the Olympics are often used as a vehicle for a wider process of social engineering and regeneration already taking place in a host city. ${ }^{22}$ In particular, he claims that hosting the Olympics fits in well with the objectives of a typical de-industrialising city and the political and economic restructuring these cities require in that process. As clearly indicated by these buildings, the Beijing case was no different and it was a perfect vehicle through which to continue restructuring the city, and the nation, along the lines of neoliberal consumption policies.

\section{Capturing the disappearing hutong: Counter Narratives and the Documentary Impulse}

Historically, much of the centre of Beijing was residential courtyard housing, set in densely populated hutong (alleyway) districts. Since the beginning of the reform period China's real estate industry has become, according to the Geneva based Centre for Housing Rights and Evictions, the fastest growing and most profitable sector of the nation's economy. ${ }^{23}$ Consequently, hutong residents have found themselves sitting on prime real estate and, as a result, land has been swiftly sold to private developers, residents have been relocated, and communities dispersed. COHRE statistics show that between 1999 and 2002, households affected by demolitions in Beijing went up threefold and that this sharp rise in demolition was directly related to the city's Olympic bid. The report also estimates that of the 1.5 million people affected by demolition and forced eviction between 2000 and 2008, around 300,000 were pushed into poverty, or deeper poverty. Clearly, this was not an image that fitted well with Beijing's narrative of a Harmonious Society, or that of the hypermodern, prosperous global city of the new State spaces. However, according to the COHRE, it not only occurred in the case of Beijing, but is a repeated narrative that is typical of all Olympics.

Despite the presence of these counter narratives and arguments, nothing of the dissent created by the Olympics in Beijing appeared in the press. Speaking about state media censorship and demolition, journalist Liu Ming explained that "we are not allowed to report disputes and protests related to redevelopment. That is seen as bad for social stability.” As in many cases of urban development in 


\section{Amps}

neoliberalising economies, such efforts to censor 'unofficial' views were strengthened by the official language used to promote regeneration as progressive and as benefitting society as a whole. ${ }^{24}$ This careful choice of wording is just one more way in which the media is involved in garnering social cohesion, ensuring that the legitimacy of any protest is undermined, if not completely silenced. ${ }^{25}$

Despite such subtle censorship and more obvious restrictions on the freedom of expression, assembly and association, there were grassroots attempts to challenge the official image of Olympic Beijing. A case in point was a series of Beijing documentaries, one example of which was Miao Wang's 2010, Beijing Taxi. Such documentaries, that fall into the category of China's 'New Documentary Movement' complicated Beijing's official, Olympic narrative, by provoking audiences into considering the Olympics as a complex political phenomenon. ${ }^{26}$ These critical documentaries were significant, particularly considering the historical context of mainstream Chinese documentary which, during the 'socialist realist' heyday of the Mao era, took the form of propaganda newsreels projected prior to feature films. These films served the purpose of communicating the mainstream political ideology of the State through Leninist political visualisation but, since the reform period they have been replaced by television in this regard. ${ }^{27}$

Most televised documentaries of this form were popular human-interest stories; a genre that has had considerable market success in the reform years. However, these state sanctioned documentaries continue to be highly ideological and, despite being more individualistic than the collectivised themes of historic socialist realism, their form and content is still officially contained. The films of the New Documentary Movement however, working illegally outside of the State system, have developed a connection to Chinese communities that exist on the periphery of official representation. As communities in dense urban areas were being destroyed, this movement became an important actor in the 'preservation' of the built environment. It is a phenomenon that has been termed the 'documentary impulse.'

Based upon what can be identified as the key principles of memory, testimony, preservation and protest, this impulse to record disappearing urban environments set the New Documentary Movement apart from mainstream 'official' productions. Lu Xinyu claims that the use of the image to offer critical interpretation, instead of dictating opinions and feelings, makes these films socially and politically groundbreaking. She claims that the film makers involved in the movement are motivated by creating a 'vision of reality' through a style and technique that contrasts with the old socialist realist documentaries, and contemporary officially sanctioned special topic programmes. She describes the movement as 'one of the most important cultural phenomena in contemporary China., 28 


\section{Amps}

\section{The Da Zha Lan Project}

The documentary impulse and obsession with preserving the built environment through image in the build-up to the Olympics, was the catalyst for a community film project located in Beijing's Da Zha Lan district; an inner city area south of Tiananmen Square made up of pre-Revolution courtyard housing and set along traditional hutong alleyways. Ancient hutong properties all over Beijing were redistributed following the revolution when housing was treated as a welfare issue for the first time. ${ }^{29}$ Despite this, some areas were also victims of Mao Zedong's efforts to modernise Beijing with Soviet-style residential apartments and, as a result, the number of hutong communities had already fallen prior to the Olympics and the latest wave of demolitions. The hutong communities that do remain in Beijing now are poor, slum-like conglomerations that are densely populated, but which still bustle with local enterprise; many courtyard homes are also the location of small businesses such as restaurants and shops. Da Zha Lan is a typical hutong locality and is described on the Da Zha Lan Project's website thus:

According to the Investigation of Urban Corners in Beijing, published in July 2005 by the Beijing Social Science Institute, the density of population in Da Zha Lan reaches 4,500 heads per square kilometer. It is extremely crowded and there are too many old houses in danger. The potential of fire is severe and there is an inadequate supply of water and electricity. Conditions of hygiene are appalling and public security is chaotic. There is an overflow of fake products and a high number of immigrants. Their daily living expenses are less than RMB 8. Da Zha Lan has become a typical slum. ${ }^{30}$

These slum-like conditions are generally cited as the justification for the current wave of demolitions of this type of hutong but, in reality, it is often little more than an excuse to legitimise new private redevelopments. This has contributed to the phenomenon known as of 'commodity housing'; the acquisition of state-owned housing stock by private developers that began after the 1991 Demolition Regulation, allowed local authorities to issue demolition permits without seeking the resident's consent. ${ }^{31}$ In the case of Da Zha Lan, the hutong has received particular attention from city developers due to its proximity to Qianmen; a gentrified tourist location close to Tiananmen Square.

Meishi Street is situated parallel to Qianmen's newly redeveloped shopping street and leads north to the Olympic Stadium along the city’s central axis. It was on Meishi Street that Da Zha Lan Project's film makers' discovered Zhang Jinli; a resident who refused to leave his home despite the threat of impending 


\section{Amps}

demolition 'to improve traffic and facilities for the 2008 Olympic Games. ${ }^{\text {, }}$ In aiming to capture a personal and street level perspective of the demolitions, the Project's leader, director Ou Ning, provided Zhang Jinli with a camera. The majority of the footage in the resulting documentary, entitled Meishi Street, was filmed by Zhang. Blurring the line between film-maker and subject, this type of documentary is key to empowering the local people affected by the upheavals that have resulted from the Olympics and the neoliberal changes in China generally. In line with the general ethos of the New Documentary Movement, this can be seen as an innovative way of emancipating the image of Beijing from the powers of official representation, rebranding, and image maintenance; all of which increasingly meet the neoliberalist demands and soft power interests of corporations and the state. This idea of emancipating the image also resonates with Lu Xinyu’s ‘vision of reality'; the idea of freeing the image from old ideological narratives and allowing it to be left open to uncontrolled interpretation.

Both these ideas are clearly present in Meishi Street's opening scenes; a montage of long take shots on what appears to be an average day in a local hutong neighbourhood. Without any voiceover narration, dialogue, or other narrative technique to link the individual images, each shot of the street seems to stand alone, leaving the viewer distanced through mere observation. It is only after these opening images that the subject of the documentary, Zhang Jinli, emerges from a manhole and chats to his neighbours who are standing nearby. With no description of the scene, or interaction with the residents, the audience only has the images to interpret. The lighting and sound are natural, there is no music and the use of long takes ensures editing does not determine tone. Instead, the audience is presented with a sense of 'visual reality.' What follows is a slightly more provocative montage of images beginning with Zhang Jinli's half demolished home and several long take shots of other houses along the same street, in similar states of disrepair. These naturalistic images of brick piles, slum like conditions and half demolished homes are in stark contrast to the spectacular television images of official Olympic Beijing. In place of the fantasy of Olympic Beijing, Zhang’s locally constructed images present us the destruction of a reality. 


\section{Amps}
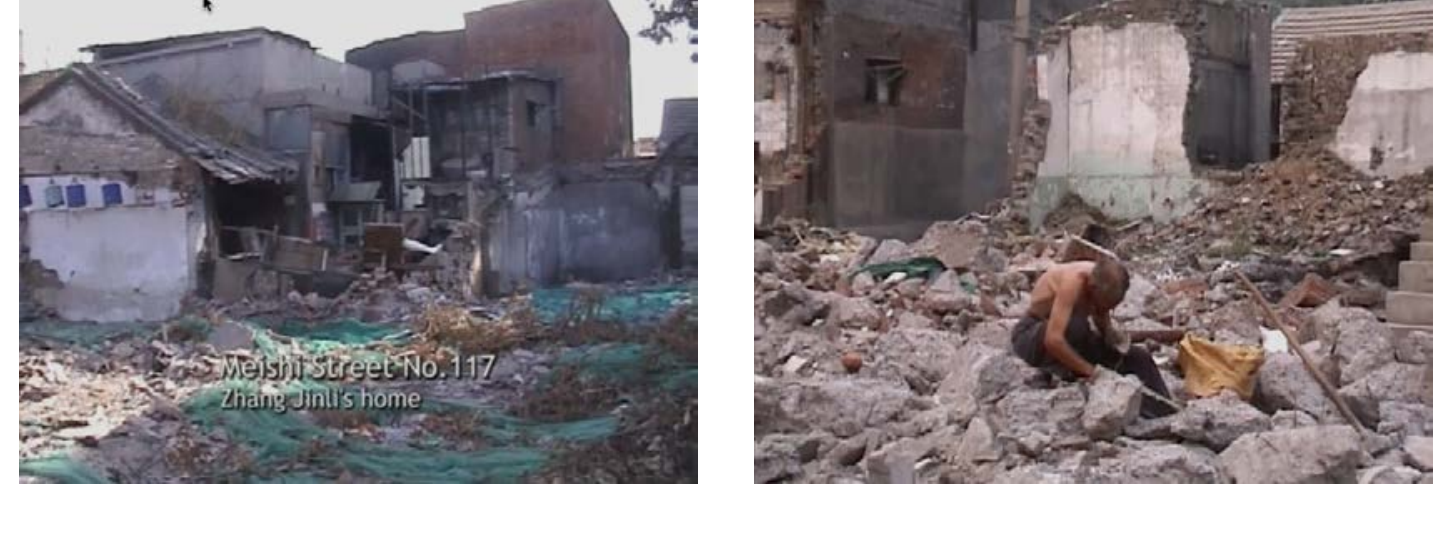

Meishi Street (2006) courtesy of Icarus Films

\section{Writing on the City}

The idea of local empowerment through the production of counter images and counter narratives comes into play ten minutes into the film when Zhang Jinli is handed the camera. Zhang's involvement in decisions around content of the final cut is not apparent. However, it is clear that Zhang uses the camera as a way of involving his community in the creation of a local counter narrative to the city's Olympic development by recording the testimonies of people being forced to leave their homes. Filming his home and the surrounding built environment is a part of that testimony and Zhang Jinli claims that it is a "memento"; a reminder for when the community is finally dispersed and the buildings are all gone. When this day comes he says, he can watch the film and remember.

It is also clear that Zhang wishes the film to bear witness to his long-term struggle to save his home from demolition. Refusing to leave without sufficient compensation, Zhang's home is colloquially termed a "nail-in” house; the name given to a property left standing in a demolished area when a resident refuses to leave. Zhang's protest is at the crux of the narrative and he turns his struggle for language, performance and representation, into the raison d'etre of the film. This is evident in his fetishisation of the protest banners he hangs from the exterior of his home, and in his appropriation of official modes of performative political language and communication.

Historically, banners have been used in public spaces in China to carry promotional socialist slogans and guidelines. In recent years they have also been used to generate public support and co-operation for changes to the urban environment, particularly large scale demolition programmes such as that threatening Zhang's home. The following three government banners hung in Meishi Street were captured 


\section{Amps}

in the film:

Relocating people in strict accordance with the law, promoting preservation of neighbourhood features.

In unison, the people support and participate actively in city government projects.

Strengthening city management, building a pleasant home together.

In response to these messages, and the authorities' use of public space to communicate their 'Harmonious Society’ propaganda, Zhang offers his own protest banners which carry their own public discourse, and which are displayed upon the very property that he is being evicted from:

To build a Harmonious Society, the government and common people must use law and reason.

The demolition and removal company has falsified agreements. The Bureau of Land Resources has broken the law in its mediation. The ordinary people are powerless and finding it hard to survive.

The demolition and removal company has falsified documents.

Zhang's creative use of banners as a form of protest is a performative act that defies the State's suppression of assembly and freedom of speech. By literally writing messages on the city, he can be seen to be reclaiming control over the changing image of the landscape. But what is most interesting is that his banners attract an audience; they are a powerful act of showing. In addition, Zhang's almost obsessive filming of his banners transforms them into fetishised images for media consumption, enabling this counter image to be taken out of its locality. Zhang also focuses attention on the public participation and observation of his protest by recording people's responses and gazes upwards at the spectacle he creates. In doing so, he highlights the power of the 'act of showing.' As with the State orchestrated spectacle, the power of his activism is in the construction of spectacle: in other people looking at him. Neither the State nor Zhang have any power without an audience.

\section{What Would Mao Do?}

Writing on the city is an act of empowerment; an act of reclaiming the image of urban space, and an act that challenges the control of the elite over public discourse. De Certeau reminds us that reading is not a passive act, but rather an active engagement that can be appropriated though interpretation. Zhang shows an awareness of this through his deliberate reinterpretation of government propaganda messages that turn his banners into an act of political subversion. To accompany the banners on the exterior of his house, 


\section{Amps}

Zhang has also posted several handwritten 'newspaper' articles. These are accompanied by pictures of Chairman Mao Zedong in a variety of different poses which explain, in detail, the injustices that Zhang has suffered at the hands of demolition and removal companies, as well as the reluctance of local government to intervene. Along with a picture of Chairman Mao waving to the crowds he has written: "Chairman Mao stands on the platform at Tiananmen Square and observes the demolition work on Meishi Street.”

To accompany a picture of Chairman Mao, this time reading, he has written the words: "Chairman Mao looks at demolition and removal documents and says; citizen's legal rights to property cannot be trampled on.” With his innovative invention of political propaganda, Zhang is making a claim for the ownership of local public discourse. He is also highlighting the performative nature of the written media by emulating propaganda newspaper narratives that use provocative images and emotive language. Zhang is not protesting by directly challenging the system, but rather, is attempting to shame it into intervening. In short he asks; what Would Mao Do? Zhang's appeal emphasises what Harvey refers to in contemporary China as the worker's moral claim for the 'traditional Maoist notion of the masses [...] whose interests were harmonious with each other and also with those of the state. ${ }^{33}$ It is an appeal and a performance that throws the Harmonious Society discourse into relief by calling upon, and reworking history, in ways that do not align with current State intentions.

As the built environment was being twisted out of all recognition, Zhang's appeal to the past also suggested both anxiety and nostalgia and, in this sense, reminds us of Braester. In particular, they recall Braester's argument that human history and memory are so deeply ingrained in the built environment that, "in the absence of familiar landmarks, they become unanchored." ${ }^{4}$ As Beijing was being reconfigured by 'transnational architectural production,' 'the local past' (as opposed to 'the national past') was being marginalised and could only survive if it could be tied to the accommodation of touristic expectations. For Zhang then, it was not just a building or a street that was being demolished and replaced by an external commodity imposition, it was human history and personal memory.

Zhang's attempts to stave off this erasure were emotively captured in his film's final scene. Bearing witness to the act of demolition of Zhang's home, this scene is characterised by erratic camera movements as he holds his camera high above his head in an attempt to scan the scene of the demolition. The shaky camerawork captures his feelings of despair and lack of control as the reason for his long protest comes to an end and his home, his memories and his history, are destroyed. In this scene, we are witness to Zhang's last attempt to capture the injustice of his forced removal and his last attempt to 


\section{Amps}

protest through showing. It is not only an emotional piece of filmmaking, but an important historical document that captures the end of one of Beijing's oldest and most traditional neighbourhoods, its urban structures, its communities and its architecture.

\section{Where two realities collide: The 'Disneyfication' of history}

From the rubble of Zhang's site of resistance grew a transient, hybrid space that embodies both the past and the future. Zhang's locality was reconfigured around the needs of the tourist and, today, Qianmen is a busy shopping district in the form of a 'Disneyfied historic downtown. ${ }^{35}$ It is a key project in the hypergentrification of Beijing's heritage sites and is symptomatic of the Olympic urban legacy as a whole.

Once an Imperial commercial district, Qianmen now invites tourists to explore its 'traditional' courtyard shops, many of which have been demolished and redeveloped in replica; something that can also be seen as another mode of 'transnational architectural production.' With much of the old slum-like hutong cleared, Qianmen and the surrounding Da Zha Lan, has become a sanitised, newly built environment that emulates a controlled, culturally specific heritage site that can be easily digested by the global spectator. To the visitor, this is a fleeting space of commoditised nostalgia and hyper-consumption. By contrast, to the residents, it is a space that no longer caters to their economic, social, or spatial needs. Even those who were not physically relocated due to the earlier demolitions are under threat of being economically displaced in the future, as the economy of the area looks ever more toward the global market.

Such stories were repeated across the city in the build up to the Olympics and, in today's China, are still being repeated across the country as the government continues to promote rapid and thorough modernisation. Across Beijing, the Olympic and non-Olympic related investment in infrastructural development over the past decade has, as in the specific case of Da Zha Lan, transformed the visual image of the city at large. Further afield it has helped create a new national identity resonant of modern global ambitions ${ }^{36}$ which turn their back on the traditional poor of China and focus attention on the one sided benefits of the neoliberal reform period. In this sense, Olympic Beijing is a perfect example of the use of architecture as a form of 'soft power' persuasion technique that has managed to transform the nation's image with apparently lasting effect. Both during and long after the Olympics, the global media was saturated with images of new Beijing; from its transnational architectural skyline with its megalomaniac proportions, to its new spaces of consumption, all of which were built at the cost of people like Zhang Jinli. 


\section{Amps}

Despite the apparently thorough imposition of this new image of Beijing through its architecture, and the concentration of the world's media on that architecture, Zhang's images of resistance continue to stubbornly preserve the old buildings that used to stand in Meishi Street. Indeed, his film represents one of the few memories left of the city's previous life and they thus offer us one of the few genuine remnants of an old, pre-Disney Beijing that continues to change and grow along neoliberal lines of development. It is in the images of his film, and other films like it, that 'real' architectural history collides with Disney. In the future, this film, and others of its ilk, may be the only places where the 'real' old architecture of Beijing exists. To use de Certeau's terminology; these optical artefacts on film may be the closest we come to historic architectural reality.

What all of this reveals is a complex relationship between architecture, history and the media. On the one hand, modern Olympic Beijing can be interpreted as an architectural simulacrum; a physically constructed spectacle. However, it can also be read as a mediated spectacle; a backdrop for television images intended to promote Beijing, and China in general, to a world of capital investment opportunities. On the other hand, it reveals the continued presence of an uncomfortable architectural and social reality in China, that continues to exist despite the huge material investments in infrastructure and urban developments witnessed in the last decade and more. Further to this, it reveals an alternative role for the media in the preservation of this historic reality.

Rather than being a mere vehicle for the presentation of the modern architectural spectacle to an uncritical world audience then, film becomes the conduit for the presentation of a hidden and seemingly shameful truth; the continued existence of poverty and a set of values that questions the neoliberal agenda of the current government. Seen in this light, the relationship between film and architecture, and by extension, society and politics, becomes a double sided game that is as complex and contradictory as China's own development; part capitalist free market liberalism, and part neo-authoritarian socialism. In both cases, architecture becomes intrinsically interwoven into a media dialogue and, indeed, becomes a form of media in itself. In the first instance, it is an object of visual entertainment that exists for the production of spectacular images, whilst in the second, architecture becomes an object of disappearance that only remains tangible through the filmic image. Architecture is not just recorded on film, it only exists on film.

This article is available on the agreed terms of open access. Users are allowed to read, download, copy, distribute, print, search, or link to the full texts of the articles in this journal without asking prior permission from the publisher or the author. This is in accordance with the BOAI definition of open access. Users are expected to fully cite and reference the sources of any material accessed under this agreement. Images supplied Icarus Films and Paul Andreu. Copyright agreements have been supplied by the author to ARCHITECTURE MEIDA POLITICS SOCIETY. For enquires on copyright of the text and its images contact the author. ms.mei@hotmail.co.uk For information on the journal see: www.architecturemps.com 


\section{Amps}

\footnotetext{
${ }^{1}$ Michel De Certeau, The Practice of Everyday Life (Berkeley: University of California Press, 1984), 92.

${ }^{2}$ David Harvey, A Brief History of Neoliberalism (Oxford: Oxford University Press, 2005), 1.

${ }^{3}$ Xuefei Ren, Building Globalisation (Chicago: University of Chicago Press, London, 2011), 6.

${ }^{4}$ Xuefei Ren, "Olympic Beijing: Reflections on Urban Space and Global Connectivity,” in: The Beijing Olympics: Promoting China's Soft and

Hard Power in Global Politics, ed. Kevin Caffrey (London: Routledge, 2011), 25.

${ }^{5}$ Ibid., 7-35.

${ }^{6}$ Anne-Marie Broudehoux, “Spectacular Beijing: The Conspicuous Construction of an Olympic Metropolis.” Journal of Urban Affairs 29, no 4 (2007): 383.

${ }^{7}$ Ibid., 389.

${ }^{8}$ Ibid., 383-399; Jacques De Lisle, “One World, Different Dreams: The Contest to Define the Olympics,” in Owning the Olympics: Narratives of the New China, eds. Monroe E. Price and Daniel Dayan (Michigan: University of Michigan Press, 2008), 17-66; Heidi Østbø Haugen, "’”A Very Natural Choice”: The Construction of Beijing as an Olympic City during the Bid Period,” in Owning the Olympics: Narratives of the New China, eds. Monroe E. Price and Daniel Dayan (Michigan: University of Michigan Press, 2008), 145-162.

${ }^{9}$ De Lisle, One World, 17-66; Price, On Seizing, 87-115.

${ }^{10}$ Broudehoux, Spectacular Beijing, 389-390

${ }^{11}$ Ibid., 390.

${ }^{12}$ Ibid, 383-399; Carolina Del Olmo, “The Role of Mega Events in Urban Competitiveness and its Consequences on People,” Universidad Complutense de Madrid. http://actuelmarx.u-paris10.fr/m4olmo.htm; Gavin Poynter, "From Beijing to the Bow Bells: Measuring the Olympic Effect," University of East London: London East Research Institute Working Papers in Urban Studies, March 2006, 1-35.

${ }^{13}$ Harvey, A Brief History, 47.

${ }^{14}$ Ibid., 120.

${ }^{15}$ Cooper-Ramo, Joshua. Brand China. The Foreign Policy Centre. 2007, 12.

${ }^{16}$ De Lisle, One World, 17-66.

${ }^{17}$ Broudehoux, Spectacular Beijing, 385.

${ }^{18}$ Joseph Kahn, “Chinese Unveil Mammoth Arts Centre,” International Herald Tribune, December 24 2007, quoted in William Callahan, China: The Pessoptomist Nation (Oxford: Oxford University Press, 2010), 4.

${ }^{19}$ Ren, Olympic Beijing, 25.

${ }^{20}$ John Hannigan, Fantasy City: Pleasure and Profit in the Postmodern. (London: Routledge, 1998).

${ }^{21}$ Poynter, From Beijing, 5.

${ }^{22}$ Ibid., 5-6.

${ }^{23}$ Centre of Housing Rights and Evictions (COHRE), Fair Play for Housing Rights: Mega Events, Olympic Games and Housing Rights. Geneva, 2007, 156.

${ }^{24}$ Sarah Glynn, ed., Where the Other Half Lives: Lower Income Housing in a Neoliberal World (London: Pluto Press, 2009), 59.

${ }^{25}$ Centre of Housing Rights and Evictions, 160.

${ }^{26}$ The movement first appeared in 1992, with films such as Bumming in Beijing: The Last Dreamers, Wu Wenguang (1992), Out of Phoenix Bridge, Li Hong (1994), No.16 Barkhor South Street, Duan Jinchuan (1996), Nostalgia, Shu Haolun (2006). These films share themes of: urban marginalisation; alternative lifestyles; radically reshaped urban landscapes; the questioning of truth and reality. They are disruptive to the official discourse and in contrast to mainstream documentary film in China, the movement leaves interpretation open. ChrisBerry and Lisa Rofel,

“Alternative Archive: China’s Independent Documentary Culture.” In The New Documentary Film Movement: For the Public Record, eds. Chris Berry, Lu Xinyu and Lisa Rofel. (Hong Kong: Hong Kong University Press, 2010), 135-155. The movement aims to give space to people and arguments that are marginalised in the official media channels. See: Paola Voci, "Blow Up Beijing: The City as a Twilight Zone,” in The New Documentary Film Movement: for the Public Record, eds. Chris Berry, Lu Xinyu and Lisa Rofel (Hong Kong: Hong Kong University Press, 2010), 99-117. It does so by avoiding techniques such as voiceover narratives with ideological motivations as was typical of the Maoist/Leninist 'socialist realist' tradition. Lu Xinyu, "Rethinking China’s New Documentary Movement: Engaging with the Social," in The New Documentary Film Movement: for the Public Record, eds. Chris Berry, Lu Xinyu and Lisa Rofel (Hong Kong: Hong Kong University Press, 2010$), 15$.

${ }^{27}$ Xinyu, Rethinking China's, 16.

${ }^{28}$ Ibid., 15.

${ }^{29}$ Centre of Housing Rights and Evictions, 155.

30 "Da Zha Lan Project," http://www.dazhalan-project.org/introduction-en/introduction-en.htm

${ }^{31}$ Ren, Olympic Beijing, 25.

${ }^{32}$ Meishi Street, directed by Ou Ning, (Beijing, China: Icarus Films, 2006), DVD.

${ }^{33}$ Harvey, A Brief History, 150.

${ }^{34}$ Braester, Yomi, Painting the City Red: Chinese Cinema and the Urban Contract (Durham, NC: Duke University Press, 2010$), 224$.

${ }^{35}$ Ren, Building Globalisation, 139.

${ }^{36}$ Ibid., 10-12.
} 


\section{Amps}

\section{Bibliography}

1. Berry, Chris and Lisa Rofel. “Alternative Archive: China’s Independent Documentary Culture.” In The New Documentary Film Movement: For the Public Record, edited by Chris Berry, Lu Xinyu and Lisa Rofel, 135-155. Hong Kong: Hong Kong University Press, 2010.

2. Braester, Yomi. Painting the City Red: Chinese Cinema and the Urban Contract. Durham, NC: Duke University Press, 2010.

3. Broudehoux, Anne-Marie. "Spectacular Beijing: The Conspicuous Construction of an Olympic Metropolis.” Journal of Urban Affairs 29 no.4 (2007): 383-399.

4. Callahan, William. China: the Pessoptomist Nation. Oxford: Oxford University Press, 2010.

5. Centre of Housing Rights and Evictions (COHRE). Fair Play for Housing Rights: Mega Events, Olympic Games and Housing Rights. Geneva, 2007.

6. Cooper-Ramo, Joshua. Brand China. The Foreign Policy Centre. 2007

7. De Certeau, Michel. The Practice of Everyday Life. Berkeley: University of California Press, 1984.

8. De Kloet, Gladys Pak Lei Chong and Stefan Landsberger. "National Image Management Begins at Home: Imagining the New Olympic Citizen.” In Soft Power in China, edited by Jiang Wang, 117133. New York: Palgrave Macmillan, 2010.

9. De Lisle, Jaques. “One World, Different Dreams: The Contest to Define the Olympics.” In Owning the Olympics: Narratives of the New China, edited by Monroe E. Price and Daniel Dayan, 17-66. Michigan: University of Michigan Press, 2008.

10. Del Olmo, Carolina. "The Role of Mega Events in Urban Competitiveness and its Consequences on People.” Universidad Complutense de Madrid. http://actuelmarx.u-paris10.fr/m4olmo.htm

11. Glynn, Sarah, ed. Where the Other Half Lives: Lower Income Housing in a Neoliberal World. London: Pluto Press, 2009.

12. Hannigan, John A. Fantasy City: Pleasure and Profit in the Postmodern. London: Routledge, 1998.

13. Harvey, David. A Brief History of Neoliberalism. Oxford: Oxford University Press, 2005.

14. Meishi Street. Directed by Ou Ning. Beijing, China: Icarus Films, 2006. DVD.

15. Østbø Haugen, Heidi. “”A Very Natural Choice”: The Construction of Beijing as an Olympic City during the Bid Period.” In Owning the Olympics: Narratives of the New China, edited by Monroe E. Price and Daniel Dayan, 146-162. Michigan: University of Michigan Press, 2008.

16. Poynter, Gavin. "From Beijing to the Bow Bells: Measuring the Olympic Effect.” University of East London: London East Research Institute Working Papers in Urban Studies, March 2006. 


\section{Amps}

17. Price, Monroe E. “On Seizing the Olympic Platform.” In Owning the Olympics: Narratives of the New China, edited by Monroe E. Price and Daniel Dayan, 87-115. Michigan: University of Michigan Press, 2008.

18. Ren, Xuefei. “Olympic Beijing: Reflections on Urban Space and Global Connectivity.” In The Beijing Olympics: Promoting China's Soft and Hard Power in Global Politics, edited by Kevin Caffrey, 7-35. London: Routledge, 2010.

19. ---. Building Globalisation. Chicago: University of Chicago Press, 2011.

20. Voci, Paola. “Blow Up Beijing: The City as a Twilight Zone.” In The New Documentary Film Movement: for the Public Record, edited by Chris Berry, Lu Xinyu and Lisa Rofel, 99-117. Hong Kong: Hong Kong University Press, 2010.

21. Xinyu, Lu. “Rethinking China’s New Documentary Movement: Engaging with the Social.” In The New Documentary Film Movement: for the Public Record, edited by Chris Berry, Lu Xinyu and Lisa Rofel, 15-49. Hong Kong: Hong Kong University Press, 2010. 